\title{
Rediscovering Nationalism
}

\author{
Venera Llunji \\ University "Hasan Prishtina" Prishtina \\ venerallunij@hotmail.com
}

\begin{abstract}
Different events which happened in Europe made not only Europeans but people all over the world think that the efforts for creating a unified Europe, and a global village is threatening national identities and livelihoods. Although globalization is considered as a buzzword of modern era, nationalism, too, is very much alive in its own way. Nationalism is not only expected to persist but also increase and intensify in response to and in opposition to forces of globalization. Thus according to Anthony Giddens, "the revival of local nationalisms, and an accentuating of local identities, is directly bound up with globalizing influences, to which they stand in opposition."(Giddens, 1994:5). Therefore this paper will try to answer the question: Is there a link between nationalism and globalization? Can these two forces be complementary rather than contradictory? Is their existence a battle of winners and losers? The paper will shortly see the pros and cons and the implications of these forces in modern societies.
\end{abstract}

Keywords: nationalism, Europe, globalization, force, implications, modern society

\section{Introduction}

\section{Political changes in the Balkans: countries in transition}

Balkans remains one of the most unstable and diverse political areas in Europe with various national events. What we see today in the Balkan political stage is mainly a result of the way the transition that these countries experienced during the 1990s, the early years of political changes turning from one- party rule to multi-party political pluralist system. Indeed, the Balkan countries placed some common features in the first decade of transition: initially they maintained continuity with their communist past; then followed the illiberal domination of the elites and the top-down politics; and, finally, they underwent a collapse of their early illiberal competitive order. Many of the features of these early years are still visible today in how local elites reach their political "agreements", in how people react through elections or protests, and how the international community exercises its authority from abroad. It is very important to understand the early stages of the transition from post-communist politics after a long period of totalitarian and one-party rule, because at this stage the foundations for stability, longevity and quality of the democratic process are set out. The first years of transition in Eastern Europe from communism to democracy caused a variety of post-communist developments regionally as well as nationally, which helps explain why in some developed countries there has been a stable democratic process, whereas in some other countries this process was more fragile and turned into a new form of authoritarianism. There is a link between what Poland, for example, pursued during its political and economic consolidation and initial detachment from the communist past and successful policies that emerged in the economy of this state. There were similar situations with other countries of Central Europe and the Baltic. Some transitions have been more successful than others; some were more dramatic and contested. When comparing different cases of post-communist countries in the Balkans, where transition is described as a deviation from the expected routes or common routes of democratic transition and consolidation, these are often defined in derogatory ways as 'insufficient' transitions (Balfour and Stratulat, 2001: 66), "delayed" (White, Batt and Lewis, 2003), 'incomplete' (International Crisis Group, 2009) 'double' (Kosotovicova and Bojicic-Dzelilovic, 2006: 223), post-conflict transitions and post-communist transitions, or as backward transitions. The transition from political authoritarianism in other forms can have different meanings and therefore has been the subject of many discussions. From a simple chronological perspective, the transition is a historical sequence of political events that are usually associated with the final stages of totalitarian authoritarian regimes respectively through the introduction of a pluralistic liberal system. From a deterministic perspective, the transition is seen as a process that leads to the consolidation of democracy, while democracy becomes the only form of state policy. Transition can also be seen as a Western hegemonic discourse of parliamentary democracy 
and (neo) liberal reform propagated and imposed in the new democracies, which in most cases legitimizes somehow an external control and external interference. Consolidation of parliamentary election policy advances in many areas of freedom and democracy and disrepute of authoritarian practices have their roots in the first period of change. Moreover, the sustainability of personal policy, the transitional nature of party ideologies, consolidation of ethnic politics, the impact of addiction from the outside and lack of trust from below are mainly a result of these crucial formative years of transition and post-communist changes. If we look back at the early stages of post-communist transition we can conclude that although the collapse of the communist system was chronological in the Balkan states, in many other countries communist regimes did not dismantle in the same way since it depended on the degree of communist ideology in a given country, depended on the extent of party control over the society, intensity of dissident politics or Soviet control over internal affairs of certain states. Communist Balkan history was a strange and difficult regional experience, as it includes various forms of communism within states. Indeed, the Balkan countries were not only political and ideological battleground between the capitalist West and communist East, but, more importantly, they became the battle field itself within the communist East. Each state in the Balkans had its own form of communism which differed on the issue of control and ideology of the party, for example, Albania, Romania, Bulgaria were totalitarian communist system, despite Yugoslavia where communist system was more liberal and more open to the west. Therefore, even the revolutionary moments of communist states which are known as the Revolutions of 1989 and sometimes even as Autumn of Nations had different experiences in different environments; somewhere the fall of communism was the most violent, somewhere more anarchic, somewhere less dramatic and somewhere more peaceful than in others. This wave of revolutions to change regimes began in Poland to continue with Hungary, East Germany, Bulgaria, Czechoslovakia and Romania. A feature common to most of these developments was the widespread use of civil resistance campaigns that showed opposition of the people to one party ruling, seeking for a change (Roberts, 1991). Revolutionary changes that have occurred in each state affected the course of liberalism or better to say the course of non liberalism which dominated the early years of transition; it has affected the degree of continuity with the past and affected the role and impact of domestic elites during this crucial period. Political changes in all these countries overthrew the communist party monopoly, which caused the emergence of political parties and movements ready to compete in the electoral arena. All post-communist countries in the Balkans removed the communist ideology and provided constitutional guarantees for the introduction of new parties within the political process. Despite claims that no element of communist parties would appear in the new political culture, political formations that emerged in the years after the fall of communism were unreformed communist party or less reformed ones, which along with anti-communist electoral alliances revived parties of the past by new political groups. (Crampton, 2002: 236). Unlike the Central European countries where a final break with the past was made, where communist politicians were discredited and new opposition elites came to power, in all Balkan countries former political elites, who were better organized and more efficient in manipulation and domination of situations of transition from authoritarian politics to competitive politics, continued to dominate party politics and state apparatus. Although in post-communist states, political elite were mostly nonCommunists who were organized in all possible forms and ways, still the presidential systems or semi-presidential in the Balkans allowed the development of personal policies and the emergence of leaders who with a strong power to control often abused the system. Because 'new' leaders and the 'old' ones were the same people: former-communists. A careful analysis of elite transformation in Croatia, Serbia, Bosnia-Herzegovina and Kosovo (while it was part of Serbia), will surely show how wars were used by nationalist leaders to extend their stay in power and to expand political machinery which limited inter-party electoral conflict. Thus the wars delayed political democratization and economic liberalization. (Baskin \& Pickering: 13:22). Milosevic dominated politics through media manipulation, nationalist propaganda and effective control of the security forces and economic resources. Croatian leader Franjo Tudjman won power on the basis of anti-communist statements through manipulation of nationalism, and through constant remembrance that nationalism was protecting Croatia from Serbian aggression. Balkan politics of the 1990s was the politics of separate states, where ethnic politics and the parallel structures in the broken and divided territories dominated. Early transition in the Balkans has caused three different stages or scopes of an illiberal politics: competitive illiberal politics in Romania, Bulgaria and Albania, semiauthoritarian nationalist politics in Serbia and Croatia, and exclusionary ethnic politics in Bosnia and FYROM. They all share common features with respect to the polarization between the government and the opposition, popular mobilization and external pressure. All mismanagement caused international concern in public activities, economic liberalization policies and privatization, as well as ethnic and minority issues. 


\section{European Union}

The countries belonging to the European Union represent the forces able to determine the victory of reason and of what are right. The EU as the main protagonist of the transition in this part of the world and according to its 1993 Copenhagen policy, is supposed to help, prepare, and in some cases even punish states while offering EU membership as the prize at the end of the hard road of transition where as it is believed and quite often emphasized by 'supervisor' of these developments, the democratic regime and economic development pay off. The reality is different. There are European Member states which imposed labor restrictions thus making impossible free circulation for citizens of other countries in Europe impossible and as such breaking the stand of equal European citizenship. Moreover, instead of people's circulation, we see free circulation of capital.

Europe and more specifically the Balkans has been considered to be the heart of nationalism. From the nationalism of the 19th century to that one which characterized the 20th century, peoples in this region have long defined themselves by a strong sentiment of national belonging, often linked to language, ethnicity and religion. But in Europe, nationalism has historically brought problems, challenges and very often wars, too.

There is a need for monitoring some of the Balkan's countries, that is without saying; however even some of the European countries, member states need monitoring as there are where citizens, although legally considered European citizens, are treated with complete disrespect, as third-class citizens, as was the case of Romanians (most of them Roma) expelled from France as illegal aliens. Obviously, economic wellbeing has not been achieved either while trying to create Europeanization of the peoples and nor has democracy flourished. Best examples are as a matter of fact all Balkan countries which have undergone the process of transition and seek for a safe road toward the integration with the exception of Slovenia and Croatia which have already reached the end of this road by becoming full-fledged EU members.

Europeans have tried and are still trying to weaken the nation-state and replace it with the European Union, which consists of supranational institutions that, over time, were meant to create a European identity. This idea might have worked theoretically speaking but when it comes to reality, it is more than obvious that there are limits to the fulfillment of this incredible project. But, what is impeding the process of Europeanization?

\section{Economic crisis}

No doubt, economic crisis is the first and the biggest problem and as such one the main obstructers. The reason to this is that economic prosperity and development were considered to be the main prerequisite of holding the European Union together. When people have jobs and all are convinced that they will have an excellent life compared to the lives of their parents or grandparents, the idea of giving up national sovereignty to supranational institutions is easier to accept. But since economic blooming is no longer a certainty, many in Europe think about the so-called benefits of the European project. Numbers of citizens do not feel being represented by common and joint politics and institutions thus causing a crisis of representation. Let's just look at the case of Greece. Greece should decide on its position and redefine its place in Europe, and this will be done by its people's vote. Greeks have been asked to vote on whether they supported the terms offered by creditors. The last time Greeks voted by a referendum was about the kind of a government they preferred after the collapse of the military junta, when the voters decided on Republican type of government. It is 28 countries of the European Union that carry the decision-making power. And while saying decision-making powers, it is thought of politically important and sensitive issues like economy, immigration and most importantly tax- payers and voters. The year 1999 will be remembered as the year when euro was launched with 19 countries entering that zone and using it, but not only EU countries. Kosovo, too, has entered the euro zone although it is not an EU member state. Even though this complex engagement is controlled by the EU Central Bank, in order not to violate the sovereignty of the EU states, the budget and tax policy are left to be organized and planned and used by the countries themselves. And although the efforts to have everything under control and well-managed, there are countries that cannot fulfill all the expectations of the European money control. Let's mention here the case of Greece and the catastrophe it experienced as a result of mismanagement which has now caused the phenomenon called "Grexit". Now other EU member states are trying to keep the problem from spreading to their own countries but at the same time political leaders see a united Europe as an imperative of this era. Will the euro zone breathe easier without countries that cannot survive without constant help of other countries, should there be other ways out by 
helping Greece again, should there be other structures created for the preservation of the economic stability in the EU and the region, remains an intriguing question.

\section{Immigration}

Immigration is a very important element to be tackled regarding its effect it has in the overall economy of Europe. No doubt, Europe has a long history of immigrants seeking refuge from different countries where lives and safety were brought into questioning. The end of the Cold War caused a number of small wars and ethnic conflicts around the world where regular troops complimented by paramilitaries almost always targeted civilian populations. Many people applying for asylum flee such "ethnic cleansing", as was the case with Bosnia in the early 1990s and Kosovo in the late 1990s. Also, with the end of communist rule many eastern Europeans believe that their aspirations for a better life can only be offered in the west. Europe's economic crisis goes hand in hand with the instability in the Middle East and other Arab countries causing more immigrants to knock on the Europe's doors. Although the European Union has a good record in human rights, there are still some areas of concern for the EU. Alarming to EU leaders is the rise of racism and xenophobia in relation to the increase in numbers of foreigners seeking entry to the EU because in times of economic difficulties and hardship, people try to find easy solutions to deep problems and as such immigrants are the easiest target of discrimination. Western European governments are in a difficult situation and considerable stress. They have to deal with immigration from lessdeveloped EU nations and assimilate the asylum seekers that arrive from the Mediterranean. They also face the emergence of anti-immigration parties such as: the National Front in France to the U.K. Independence Party and recurring terrorist attacks by nationals who received training in the Middle East. Simultaneously, they have to deal with stagnating economies and pervasively high unemployment. The combination of economic malaise and resistance to immigration is seriously challenging the cohesion of the European Union. But, if the EU is to be a true upholder of human rights principles, it must take steps to ensure that human rights are offered to all its inhabitants, citizen or non-citizen.

\section{Integration}

Next issue that EU governments face is the issue of integration. Views differ across Europe on the goal of integration and appropriate strategies to achieve it. Shrinking and aging populations make the EU governments operate under the idea that immigration could help in easing the problem. One of the main responsibilities of the EU is ensuring integration at the local and national levels since immigration, economic growth and social cohesion require a special focus on integration. The EU has the capacity to address issues such as family reunification, laws on racial and religious discrimination, strategies on employment, social inclusion and cohesion, and health. The Amsterdam Treaty of 1999 requires that EU member states to address not only discrimination on grounds of race and religion but also to legislate on racial discrimination in employment and services, and to provide assistance to individual victims while banning religious discrimination. However, many foreigners find it hard to adapt to new environments especially when they have to agree to the very strict citizenship laws, and face extensive cultural barriers. And it's not only the immigrants that face problems; governments within EU are also being challenged by the phenomenon. According to EU norms asylum seekers are not to leave from one country to another if they have already reached one specific country. What happens is that quite often asylum seekers do exactly the opposite; they move from one EU country to seek for an asylum to the other EU country which is causing now a debate among governments questioning the Schengen agreement and border controls among EU member states. One such debate came up with the accusations of the government of the German state of Bavaria to the Italian government of allowing asylum seekers to leave Italy and request asylum somewhere else in the EU bloc. Nonetheless, Italian government requested for more empathy and solidarity among EU members in the reception of refugees. That is why the government of Bavaria suggested that EU member states should decide on suspending the Schengen agreement. Criticism of insufficient border control within EU countries is another debate as many groups argue that the lack of internal border control offers great opportunities for terrorists to move freely from one EU country to another one. This is very true nowadays but at the same time, this debate brings into questioning one of the main pillars of the European Union, that of the free movement of people. Although there is a great cooperation among EU governments, yet again it is impossible to follow and control every potential threat. Initiating such debates only shows that even after many years of supranationalism Europeans are discussing again their national identities. President of France, Sarkozy started a debate on 'what it means to be French' putting the Muslims of that country into an awkward and strange position, making them question their identity. Protests in 
Germany, in Pegida led to similar debates all over the Europe and controversies as well. Such debates then make Europeans to deal with difficult questions that have stagnated for many years. These problems put into question globalization which means the free movement of people, goods and services. But since for some proponents of globalization, such as Robert Reich, former US Secretary of Labor who considers it as "the end of geography, the end of distance, and the absence of borders", even many Europeans think that globalization is a threat to their way of life and though EU was built on the principles of globalization there are doubts that it will remain successful.

\section{Conclusion}

Great changes that happened during the decades in Europe and the world in general proved that a system of cooperation and security based on the norms of international law is absolutely necessary. Therefore, the 21 st century fights for a democratic international life, for the consolidation of peace, for the free and independent development of nations, as well as for the encouragement of economic and political order. In order to understand the current context of the community policies, it is necessary to see what the issues impacting Europe and the Balkans were and what the directions of the European states are. By its very structure, the current paper did nothing more than present the difficulties and problems of the European integration, This paper shows that the process of European integration still has many opponents, lacking the quality of an accomplished process; however, ensuring the active participation in the solving of all the issues in a transparent and democratic manner, is the responsibility of the states comprising a whole: the European Union.

\section{References}

[1] Balfour,R. \& Stratulat,C. "The Democratic Transformation of the Balkans", EPC Issue Paper, No. 66 (November 2011).

[2] Baskin, M. \& Pickering, P. Democracy, the Market and Back to Europe :Chapter 13: Former Yugoslavia and Its Successors. Retrieved:

[3] http://pmpick.people.wm.edu/research/FormerYugoslaviaBaskinPickering.pdf

[4] Crampton, J.R. (2002). The Balkans since the Second World War. Pearson Education Limited. Great Britain.

[5] Giddens,A. (1994) Beyond Left and Right: The Future of Radical Politics, Cambridge: Polity Press.

[6] Kostovicova,D.\& Bojicic-Dzelilovic,V.(2006) "Europeanizing the Balkans: Rethinking the Post-Communist and PostConflict Transition", Ethnopolitics, Vol. 5, No.3.

[7] Roberts,A. (1991). Civil Resistance in the East European and Soviet Revolutions, Albert Einstein Institution, 1991. ISBN 1-880813-04-1. Available as pdf from:aeinstein.org

[8] White,S., Batt,J., and Lewis,P. (2003). Developments in Central and East European

[9] Politics, Durham, Duke University Press. 